\title{
Article
}

\section{Is the gas industry a good neighbour? A comparison of UK and Australia experiences in terms of procedural fairness and distributive justice}

Witt, Katherine, Whitton, John and Rifkin, Will

Available at http://clok.uclan.ac.uk/24326/

Witt, Katherine, Whitton, John ORCID: 0000-0001-6391-5740 and Rifkin, Will (2018) Is the gas industry a good neighbour? A comparison of UK and Australia experiences in terms of procedural fairness and distributive justice. The Extractive Industries and Society . ISSN 2214-790X

It is advisable to refer to the publisher's version if you intend to cite from the work.

For more information about UCLan's research in this area go to

http://www.uclan.ac.uk/researchgroups/ and search for <name of research Group>.

For information about Research generally at UCLan please go to http://www.uclan.ac.uk/research/

All outputs in CLoK are protected by Intellectual Property Rights law, including Copyright law. Copyright, IPR and Moral Rights for the works on this site are retained by the individual authors and/or other copyright owners. Terms and conditions for use of this material are defined in the policies page. 


\title{
Manuscript Details
}

\section{Manuscript number}

Title

Short title

Article type
EXIS_2018_80_R1

Is the gas industry a good neighbour? A comparison of UK and Australia experiences in terms of procedural fairness and distributive justice.

Is gas a good neighbour?

Research Paper

\begin{abstract}
Australia and the UK share much in common in their social, governance and legal systems. Would approaches to unconventional oil and gas development also be similar? In this article, we examine the different experiences of local communities regarding unconventional oil and gas development in Queensland, Australia and England, UK. We question whether the onshore gas industry makes a 'good neighbour' in two different contexts that share one common legal background. We consider procedural fairness within the context of land access processes and discourses of individual and collective property rights generated by unconventional gas development in each country. Land access policy and practice have developed significantly in Australia to recognise the rights of existing landholders, including Traditional Owners, and in England, to clarify mineral and resource ownership rights. We consider distributive justice within a conceptual framework of social sustainability relating to communities and local social impacts from development. We review how governments at various levels have attempted to resolve such issues. We conclude that the unconventional gas development experience is heavily context dependent and cannot be described by a simple narrative, nor by snap-shot baseline and impact studies. We suggest that there remains much to be learned about regulating the industry.
\end{abstract}

\section{Keywords}

Taxonomy

Corresponding Author

Corresponding Author's Institution

Order of Authors

Suggested reviewers

Opposed reviewers fracking; procedural fairness; distributive justice; land access; energy.

Social Science, Environmental Science

Katherine Witt

University of Queensland

Katherine Witt, John Whitton, Will Rifkin

Jeffrey Jacquet, Peta Ashworth, Julia Haggerty, Kathryn Brasier

Andrea Walton, Thomas Measham

\section{Submission Files Included in this PDF}

\section{File Name [File Type]}

Cover Letter-Gas a good neighbour- revised.docx [Cover Letter]

Response to Reviewers Good neighbour 24-9-18.docx [Response to Reviewers (without Author Details)]

HIghlights_Gas a good neighbour.docx [Highlights]

Title Page - Gas a good neighbour (1).docx [Title Page (with Author Details)]

Witt et al_Good neighbour_Resubmission_22-9_KW-WR-KW.docx [Manuscript (without Author Details)]

To view all the submission files, including those not included in the PDF, click on the manuscript title on your EVISE Homepage, then click 'Download zip file'. 
Date 24 September 2018

Editor/s

Extractive Industries and Society

Special Edition: 'Social facets of fracking'
Centre for Coal Seam Gas

Level 8, Sir James Foots Building

Cnr College and Staffhouse Road

St Lucia QLD 4072 Australia

Director

Professor Andrew Garnett

CRICOS PROVIDER NUMBER 00025B

Dear Darrick and EI\&S editors,

\section{Re: Witt, Whitton and Rifkin article submission}

Thank you for the opportunity to revise this manuscript for the Special Issue on the social facets of unconventional gas development. The reviewers' comments were very helpful and enabled us to refine our argument and more clearly define our focus. We hope the revisions are to your satisfaction.

Thank you again for your patience and the extension of time.

Yours faithfully,

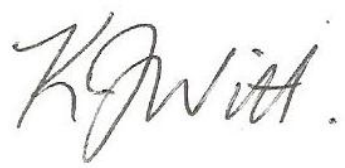

Dr Katherine Witt,

Corresponding author

k.witt@uq.edu.au 


\section{Response to Reviewers - Is Gas a Good Neighbour?}

\section{Reviewer 1}

Nice work! The paper provides an interesting comparative analysis of regulatory environments that govern unconventional gas development in the UK and Australia. The focus on procedural fairness and distributive justice is very relevant given the importance of those two elements in community acceptance. The contextual similarities and differences influencing community outcomes are clearly outlined and analyzed.

Thank you.

Some statements would need to be substantiated and referenced.

E.g P5: Regulatory responses in the UK have raised significant issues regarding democracy and fairness for communities impacted by shale gas exploration (Whitton et al 2017) inserted

P8: Researchers have highlighted this tension between private property and public value and the extent to which citizens' rights extend (Jacquet et al 2018) inserted

P6: Other regulatory responses in Australia: Need to ensure that it is clear which Australian jurisdiction you are referring to in this paragraph.

Thank you. We refer to all levels here and have reworded to make it clearer. We have amended the text throughout so that it is clear we focus on experiences in Queensland and England.

\section{Reviewer 2}

This manuscript presents a comparison of Australian and UK cases in terms of procedural and distributive justice. The aim is to compare the specific features of each case and examine the lessons learned-specifically in terms of increasing the fairness and social sustainability of shale/coal seam gas.

Though this Australia-UK comparison has potential merit, I found substantial problems with the manuscript, both in terms of the underlying conceptualisation and application. These issues should be addressed thoroughly before I can recommend publication.

We have attempted to address all the following points and hope the changes are to your satisfaction.

One concern is that the concepts of "Australian" and "UK" unconventional oil and gas development are weakly defined. The majority of the discussion is on Queensland, but certain points about public participation for example relate to the state of Victoria (e.g. p.4 - which has a completely different take on the unconventional gas issue). As there is no single Australian policy position at the federal level, policy is made by the states. Queensland has a very different stance on development to Victoria. The authors therefore do some weaving in and out of different scales of governance to make different points about "Australia".

We have explained the different level of government more clearly and focussed the comparison on experiences in Queensland, where CSG has been developed. The reference to Victoria has been removed.

Similarly the UK focuses specifically on the English planning system as Scotland has a current ban and Wales an effective moratoria (no applications are currently being considered). Realistically this is an 
England-Queensland comparison, rather than UK-Australia and this is a more difficult governance comparison (country-to-state level). At least this needs to be clarified and better articulated throughout.

We agree that the nature of this comparison needs to be made clearer. We have endeavoured to do so with changes in text throughout, being more specific about which Australian state is the focus and how generalisations might be inferred from that comparison.

The underlying need for an ethical analysis of shale gas needs to be better established. Though there is a fair amount of relevant literature cited on the topic, various key sources on the issues of ethics and fairness specifically are missing. Evensen's paper in Environmental Values, de Melo Martin et al. or Lignum et al. would be useful in setting up the need for an ethics/ justice-based analysis:

Evensen, D.T., 2015. Policy decisions on shale gas development ('fracking'): the insufficiency of science and necessity of moral thought. Environmental Values, 24(4), pp.511-534.

de Melo-Martín, I., Hays, J. and Finkel, M.L., 2014. The role of ethics in shale gas policies. Science of the total environment, 470, pp.1114-1119.

Dignum, M., Correljé, A., Cuppen, E., Pesch, U. and Taebi, B., 2016. Contested technologies and design for values: The case of shale gas. Science and engineering Ethics, 22(4), pp.1171-1191.

Thank you for noting these relevant pieces to be cited. We do not aspire to a full ethical analysis but have used these reference to justify the need and our use of the terms procedural fairness and distributive justice.

Similarly a range of country-down-to-county level analyses of environmental justice in relation to shale gas would be beneficial. Specifically those that already cover the UK in detail such as Cotton's paper in Local Environment, or Lacey et al's paper in JoCP on social contract in the Australian case are relevant:

Cotton, M., 2017. Fair fracking? Ethics and environmental justice in United Kingdom shale gas policy and planning. Local Environment, 22(2), pp.185-202.

Lacey, J. and Lamont, J., 2014. Using social contract to inform social licence to operate: an application in the Australian coal seam gas industry. Journal of Cleaner Production, 84, pp.831-839.

Thank you, we are familiar with this line of argument and will boost the referencing in this article. We have drawn on both Cotton and Lacey et al. We removed paragraphs on utilitarian theory and social welfare, etc so as not to give the impression of being a full ethical analysis. We hope this more delineated approach works.

Other papers are also of relevance, specifically Meng's paper on 'fracking justice' or significant case studies in the USA

Meng, Q., 2018. Fracking equity: A spatial justice analysis prototype. Land Use Policy, 70, pp.10-15.

Fry, M., Briggle, A. and Kincaid, J., 2015. Fracking and environmental (in) justice in a Texas city. Ecological Economics, 117, pp.97-107.

Clough, E. and Bell, D., 2016. Just fracking: a distributive environmental justice analysis of unconventional gas development in Pennsylvania, USA. Environmental Research Letters, 11(2), p.025001. 
Again, thank you for these relevant references. We can see there has been much done in this field with far more sophisticated analyses of ethics dimensions than the one presented here. Here, we have compared experiences of gas development in the different jurisdictions using the frames of PF and DJ, rather than attempting.

The methods section is misleading. On first reading I was unclear if this paper was reporting on primary research (based upon community-focussed fieldwork), or secondary analysis and reporting. It turns out it was the latter. This needs to be much clearer. I suggest removing this section and calling the paper what it is - a discussion/review paper rather than an empirical paper. It is an editorial decision therefore if a more discursive approach is suitable for the journal.

We have rewritten with an explicit statement about being a secondary analysis to make this clearer. The paper includes insights from extensive empirical and ethnographic work in the Queensland context. The insights on the UK are more conceptually based. So, it is not either 'empirical' or 'notempirical'; it is a hybrid. We have clarified that in the paper.

The concepts of justice used in this paper are simplistic and incomplete. This requires substantial reworking before publication can be considered.

We have reworked sections and acknowledge that we have only used elements of the concepts and stated that is not a full ethical analysis, rather a comparison of strategies developed to improve procedural fairness and distributive justice in relation to land access and cost/benefit distribution. We set about to ask and answer the question of whether gas can be a good neighbour? We recognise that being' a good neighbour' means satisfying expectations for procedural fairness and distributive justice, hence the use of these concepts as frames for comparison.

The concepts that needs work are:

Environmental justice - there is very little literature cited on what it is, and what the underlying concepts are that make something fair. EJ is also commonly recognised as involving recognitionbased justice as well as procedural/distributive dimensions. This is not mentioned, and should be included in the analysis - David Schlosberg in particular. This requires substantial reworking and referencing. Specifically on pages 7 and 8 the discussion of procedural and distributive justice to set up the analysis, is very thinly defined. There is a rich literature on each, and the underlying ethical dimensions of these concepts (there are no citations of relevant literature in the definition of each).

A focus on environmental justice would take the paper in a direction different from the one intended. A contribution of this paper is the rich empirical work from Queensland on economic and social effects of onshore gas development, reflecting more than five years of fieldwork. We have published little on that in the academic literature, though the data are widely referred to in the community, government, and industry sectors in the region. Our social and economic analysis has been well received in international forums. Environmental justice deserves greater attention, as you suggest, but again, it is not our focus in this paper. We have responded by reworking sections so as not to give the impression of this being a full treatment of environmental justice - which it clearly is not.

There is no mention of the emergent paradigm of energy justice (the work of Sovacool, McCauley, Jenkins etc.). This is relevant as it links issues of planning concerns with those of energy resource use and climate change (the interlink is mentioned but not discussed in detail here).

That is a good link, thank you. We have mentioned it in the concluding section of the paper as an area for further development. 
There's no mention of the literature on energy sacrifice zones which is beneficial to understanding the ethics of distributive fairness inherent in resource extraction.

Good point. That aligns with the concepts that you introduced above about environmental justice and energy justice. We now refer to this area of focus as a 'next step' in the concluding section of the paper.

There is no mention of social license to operate (and its critiques).

We are well immersed in the social license debates - conceptual and 'real world', but we decided not to open this can of worms for this piece, sticking instead to 'community acceptance'. As you note, however, the concept will emerge for readers. So, we have included reference to social license with a note about its critiques in the paper.

More specific issues

Page 1- the allusion to moral fibre is odd. Consider rephrasing.

It was meant to infer the old agrarian notion of 'country folk' being morally superior to 'city folk' (which still persists in some places). That argument does not carry weight in this paper though, so has been deleted.

Page 2 - procedural and distributive fairness are not technically ethical principles - they are ethical problems which would be resolved differently by applying different ethical principles (like highlighting welfare or duty for example). Justice as fair distribution is rather put in opposition to utilitarianism later on in the paper. But this is a simplistic dichotomy.

We chose to keep the ethical references simple and simplistic in this paper, as it is introducing concepts that many readers may not be entirely familiar with. Nonetheless, we have improved the precision in our mentions in this piece. Reference to utilitarian ethics is removed to avoid confusion.

Page 2- The expectation that community responses would be similar from the UK and Australia is an assumption - more substantial evidence is needed to back up this claim, given that there is now substantial empirical research on community shale gas responses in each country.

We have now qualified our mention of the expectation that community responses would be similar. It is all a question of what counts as 'similar', some would argue.

Page 7 The authors argue that the UK is ambivalent to fracking - that is broadly true, but the Government's own figures suggest that public acceptance is falling. I suggest the Energy and Climate Change Public Attitudes Tracker surveys for up to date figures to flesh out this ambivalence/falling support. I think waves 25 is the latest. The figures are very similar to those of the CSIRO study.

Thank you. We have used the Wave 25 - what a wonderful resource! Ambivalence in UK remained the same as last year. In the UK, ambivalence appears to be related to lack of awareness and knowledge about the industry. The CSIRO study surveyed people living in the gasfields region, where we might expect them to have higher levels of knowledge and awareness.

Page 7 - What is the justification for saying that Australia is more influenced by the US than the UK is? Clear statements by Coalition/Conservative government officials in the last 7 years have made clear that the UK intends to mirror the economic successes of the United States from shale gas.

The main basis was the underlying model for granting petroleum licenses where the UK uses a European- originated model that tends to place controls over the pace of development (so can slow 
it down or speed it up as needed) and Australia adopted the US model which does not control the pace of development but allows market forces to alone to drive it. We can see though, that modern planning policy is being more influenced by the US shale gas experience. We hope we have clarified this point. The point is not so much about the level of influence as about the ability to see parallels. Australia has much more onshore gas exploration and development than the UK, and in that way, Australians are responding to gas development on our shores.

Page 9 - the description of utilitarianism is simplistic. A more full definition is needed - this is a simple description of welfare utilitarianism (which is not the whole of utilitarian thought).

Recognising that this requires quite a bit of explanation we decided to delete the section on utilitarian ethics and keep simply to the specific elements of justice delineated.

Page 9 - The Mill reference needs a citation.

Mill has also been deleted

Page 9 - Whitton 2018 needs a reference in the bibliography.

Thank you. This has been amended

Page 17 - The conclusion that community visioning to achieve social sustainability is rather speculative. I am sceptical of the assertion that a method of public participation will automatically enhance dialogue and hence procedural justice. There are lots of participatory methods available which are similar in scope to the visioning process suggested, but these alone do not ensure justice. I contend that it is only through political commitments to share power through participatory means that this might be achieved. The method used should therefore be specific to decision/outcome at hand.

We have reworked the conclusion section, noting that community visioning is among many elements needed, but it is not sufficient alone. Thank you for your insights and recommendations. 
Is the gas industry a good neighbour? A comparison of UK and Australia experiences in terms of procedural fairness and distributive justice.

\section{Highlights}

Compares unconventional gas development in UK and Australia through a lens of procedural fairness and distributive justice

Despite similarities in legal and political systems, the unconventional gas development experience is heavily context dependant.

Advances are being made toward better procedural fairness and distributive justice but the gas industry is still learning to be a good neighbour in both countries. 
Is the gas industry a good neighbour? A comparison of UK and Australia experiences in terms of procedural fairness and distributive justice.

Katherine Witt ${ }^{1}$, John Whitton ${ }^{2}$ and Will Rifkin ${ }^{3}$

1. Centre for Coal Seam Gas, The University of Queensland, Australia

2. UCLan Energy, University of Central Lancashire, Preston. UK.

3. Hunter Research Foundation Centre, University of Newcastle, Australia.

Funding: The Centre for Coal Seam Gas is funded by The University of Queensland and partners in the gas industry (Arrow Energy, APLNG and Santos) 


\title{
Is the gas industry a good neighbour? A comparison of UK and Australia experiences in terms of procedural fairness and distributive justice.
}

Keywords: fracking, procedural fairness, distributive justice, land access, energy

\begin{abstract}
Australia and the UK share much in common in their social, governance and legal systems. Would approaches to unconventional oil and gas development also be similar? In this article, we examine the different experiences of local communities regarding unconventional oil and gas development in Queensland, Australia and England, UK. We question whether the onshore gas industry makes a 'good neighbour' in two different contexts that share one common legal background.

We consider procedural fairness within the context of land access processes and discourses of individual and collective property rights generated by unconventional gas development in each country. Land access policy and practice have developed significantly in Australia to recognise the rights of existing landholders, including Traditional Owners, and in England, to clarify mineral and resource ownership rights. We consider distributive justice within a conceptual framework of social sustainability relating to communities and local social impacts from development. We review how governments at various levels have attempted to resolve such issues.
\end{abstract}

We conclude that the unconventional gas development experience is heavily context dependent and cannot be described by a simple narrative, nor by snap-shot baseline and impact studies. We suggest that there remains much to be learned about regulating the industry.

\section{Introduction and overview}

As a former British colony, Australia has inherited many of its governance structures from the UK. A history of British sovereignty has, to a large (although lessening) extent, defined Australia's culture and society. That includes predominantly utilitarian attitudes toward land and natural resources, expectations of secure private property rights, and expectations of public participation in decisions about land use. In both the UK and Australia, though in different eras and at vastly different scales, agricultural production has been paramount to economic growth and prosperity, as well as producing food and fibre. However, in more recent times, rural landscapes in both countries have been expected to provide a much broader range of public goods and services, including carbon and water storage, rural amenity (particularly in the UK), biodiversity, and increasingly, energy. Given the shared history that shapes land use values, one might expect the development of unconventional gas industries in rural areas to follow similar paths. They may differ at different points on similar trajectories, though both countries are still at relatively early stages of development compared to the US or Canada.

Despite the common expectation that rural landscapes in the UK and Australia will provide multiple benefits for multiple users, including energy supply, questions remain about how a new energy industry, such as unconventional gas, should make its entrance into existing socio-cultural and biophysical landscapes and how it can coexist alongside other land uses and land values. This last question about co-existence is particularly relevant since unconventional gas production typically 
involves the use of private, often farmed, land by gas companies who have been granted a petroleum extraction license from the government (Curnow et al. 2017). With multiple parties having been ceded rights to the land, questions arise as to who should have agency in decisions about whether development should go ahead or not, what procedures are necessary to gain acceptance and whether what is done in one situation is applicable in another. We address these questions in relation to concepts of procedural fairness and distributive justice as key drivers of community acceptance and broader 'social license ${ }^{1}$ ' of the industry (Lacey and Lamont 2014; Moffat and Zhang 2014). As the unconventional gas industry seeks to develop and expand, and with scientific uncertainties surrounding possible health and environmental impacts (de Melo-Martin et al. 2014; Keywood et al. 2018), there is an increasing need to understand and consider such justicebased concerns in planning and land use decision making (Evensen 2015).

Our conclusions about co-habiting the landscape fundamentally relate to the question, 'Is the gas industry a good neighbour?' We respond by examining and comparing experiences of the early stages of unconventional gas development in Australia and England, UK. IN these settings, one could expect, given the common political heritage and development pathways, government and community responses might also be following similar paths. To examine and compare experiences with land access and co-existence requires a focus on regions where some unconventional gas activity has already occurred. For this reason, we focus on England in the UK (Scotland has a ban and Wales has a moratorium on the process of fracking since 2015), and Queensland, Australia (most other Australian states have some form of moratorium in place).

\section{Methods}

This paper is based on secondary analysis and reporting of research and experiences with unconventional gas development. The Australian case material is drawn from academic and grey literature as well as public documents. Additionally, the authors have been engaged in participatory social research in the arena over the past six years. Participatory methods include interviews with key informants in ten towns on social and economic changes and internal tensions within each community. Interview data are accompanied by analysis of 15-year trends in key social and economic indicators, ranging from housing costs and unemployment to business income and crime rates (CCSG 2017). This rural fieldwork has been supplemented by extensive engagement in the state's capital city of Brisbane. That has occurred through ongoing interactions with staff, policy makers, and executives in the state government and the natural gas industry.

We use England as a comparison and case study on which to apply learning from the fieldwork and analysis of literature in Australia. In England, shale gas exploration is at an early stage dominated by a polarized narrative of those either for or against - that is, those touting either the promises of economic prosperity or claiming procedural and environmental injustices. With this polarised narrative in mind, we have adopted a conceptual framework related to social sustainability as the

\footnotetext{
${ }^{1}$ The term 'social license', while often used, is referred to hesitantly here as it has been criticised as being industry-centric and inferring a 'tick-box' approach rather than an ongoing and dynamic relationship between industry and community (Owen and Kemp 2012). Critiques indicate that it is too heavily reliant on an impetus to achieve consensus rather than being pursued in relation to justice-based theories of social contract (Lacey and Lamont 2014).
} 
basis for a critical review of salient pieces of academic and grey literature review on shale gas planning and land access rights. To this body of work, we have analysed elements of procedural and distributive justice analysis, as recorded in Tables 2 and 3 . This evidence helps to illustrate the fundamentally different views on what terms of reference the UK planning system ${ }^{2}$ should consider when processing shale gas planning applications and where agency for planning decisions should be based - with government or citizens. Such illustrates enable examining how the varying parties have "creatively constructed" the governance expectations and practices for their gas development reality (Whitton et al. 2015, 128).

\section{Contextual similarities and differences influencing community outcomes}

Reflecting its history of British sovereignty, Australia follows the UK's Westminster system of democratic governance in which local representativeness, choice and public participation are pillars for fair democratic processes. Planning laws in both the UK and Australia emphasise the importance of public participation in land use decision making, and both jurisdictions aim to balance the protection of private property rights with economic development to advance the public interest (Stokes 2012). In relation to unconventional gas development, public participation processes have an increasingly prominent role as they provide mechanisms for addressing conflict between different groups within society and opportunities for a wide range of interests to influence (albeit to varying degrees) the decision making process. However, while there is common agreement about the principle of public participation, there are differences between England and Australia and within each country in the ways that it is implemented, particularly in relation to local planning processes and in the granting of petroleum licenses. Indeed, inadequate public participation is often seen as a major contributing factor in social conflict over land and resource use generally (Innes and Booher 2004), and more recently in relation to shale gas (North et al. 2014) and other energy projects (Cuppen 2018).

\subsection{The role of local government and public participation in planning}

In Australia, land use planning is the responsibility of the individual states. Where triggered, it is also subject to laws from the central government protecting the environment and cultural values. As a result, approaches to land use planning can and do differ. Queensland, where CSG development received government support, has a relatively "top-down" approach to planning, at least where significant projects are concerned. The Queensland government states it will work "closely" with local governments to develop land within pre-identified "priority development areas" (Queensland Government 2017). However, it does not provide measures to increase local capacity, consensusbuilding, or decision-making powers. In this model, the Queensland government determines areas where development would significantly advance what they designate as the public interest. It then engages in public "consultation" activities that are characterised by critics as mostly geared toward placating opposition and gaining local consensus for the proposed development (Luke et al. 2014; Espig and de Rijke 2016).

\footnotetext{
${ }^{2}$ For a summary of the differences between planning systems in England, Northern Ireland, Scotland and Wales, see House of Commons (2016).
} 
The UK has been on a trajectory of reducing the central government's role in planning and increasing the powers and autonomy of local governments and local communities (Stokes 2012). However, a review of UK shale gas governance (Whitton et al. 2017) concluded that the opportunities for public and community interests to be involved in shale gas decision-making are limited and frustrated by a sluggish county-level planning system. For example, Lancashire County councillors rejected planning consent for Cuadrilla's application to drill and frack a total of eight wells at two sites in Lancashire. The decision was rationalised on the grounds that the well pads and equipment would have an unacceptable visual impact and create too much noise. However, the company's appeals against these rulings look to take the decision away from local representatives to national government ministers and the Secretary of State as noted by Rattle et al. (2018) and Szolucha (2018).

A comparison of approaches in relation to unconventional gas development shows how the voice and role of local (county) governments has been overpowered by higher levels of government in both jurisdictions.

Public input into decisions about resource development in Australia - i.e., project approval for CSG development - occurs through broader democratic processes of voting for a political party in state government elections and through 'community consultation' required in formulating an environmental or social impact assessment. Public input into operational decisions once development licenses are in place can occur, at least in Queensland, through community consultation committees, which have been required by conditions for project approval from the Coordinator-General's office (what is referred to as 'conditioning' a project). Companies were also conditioned to conduct quarterly opinion surveys during their first five years of development, to keep registers of complaints by local residents and other stakeholders, and to negotiate for land access from landholders. This last item is a significant and ongoing area of concern, which we will expand on below.

\subsection{Private property rights and the granting of petroleum licenses}

While expectations for landholders' private property rights are similar in Australia and the UK, the rights granted to petroleum licensees are quite different. The UK follows the 'North Sea' model for granting petroleum licenses, which retains high levels of government control over the scale and pace of development. Australia follows the 'North American' model, which gives more autonomy to gas companies and allows market forces to determine the scale and pace of development (Hunter 2014).

In both countries, onshore exploration for oil and gas requires a license. The license grants exclusive exploration rights (i.e., to drill boreholes and conduct testing) to develop oil and gas production. The rights granted by a "landward licence" do not include access rights - that is the right to access the land surface and potentially also water resources below which the resource might reside. The licensee is required to obtain other consent under current legislation, including necessary planning permissions from appropriate local authorities (Whitton et al. 2017). This process is similar in Australia, where the licensee must gain consent from the landowner for land access, although the landowner does not have the right to withhold consent, without taking the matter to court.

In the UK, underground mineral and petroleum resources are owned by the Crown Estate. The process of exploring and extracting these resources is governed by a system of national laws. Changes to trespass law were included in an Act of Parliament in 2015 (Government 2015) to enable 
oil and gas developers to access from neighbouring land underground resources that are over 300 metres beneath an individual's property. That is despite 99 percent of 40,647 responses to a consultation on the proposed changes being in opposition to the development (DECC 2015). Section 43 of the Infrastructure Act 2015 provides that there is now a right to drill for oil or gas at a depth of 300 metres or more below the surface. That removes the need to gain consent from the landowner to access land at this depth or below and essentially permits hydraulic fracturing to occur below private property without the landowner's consent. For access to resources less than 300 metres below the land surface, the onus remains in shale gas operators to acquire landowner consent and to agree on appropriate compensation.

Arguments for these changes to the law included the mitigation of lengthy delays to exploratory activity and the costly and time-consuming legal processes resulting from public opposition activity. In recognition of collective landscape values, the UK Government has stated within draft regulations (Government 2015) that hydraulic fracturing must take place at a depth more than 1,200 metres below protected areas such as National Parks, Areas of Outstanding Natural Beauty, the Broads and World Heritage sites. This limit is qualified by stating that drinking water is not normally found at depths below 400 metres (DECC 2015). At present, the approach of the UK has demonstrated elements of bipolarity, with government support for such resource development being explicit alongside a requirement for strict regulation and awareness of potential environmental impacts.

Underground resources in Australia also belong to 'the Crown'. In practice, the individual state governments receive royalties from the development of such resources and grant rights to explore and to develop them, including rights to access private land to extract those resources. The lack of landholders' rights in this process has been the subject of strong opposition from affected communities, which we discuss further in this article.

While the Australian federal government at the time remained quiet on the issue of unconventional gas development, the Queensland state government provided financial incentives similar to those for the UK (Towler et al. 2016) to support the oil and gas industry in launching the CSG mega projects. Development was then spurred by a surge in gas prices.

\subsection{Government and regulatory responses}

Regulatory responses to planning applications for shale gas developments in the UK have raised significant issues regarding democracy and fairness for communities impacted by shale gas exploration. Rattle et al. (2018) and Szolucha (2018) provide examples in Lancashire and Yorkshire. To summarize, the views of local people against shale gas development were essentially ignored by central government by overruling local government decisions against shale gas developments. Whitton et al. (2017) argue that such decisions are all the more controversial given the UK Government policy commitment to 'localism'.

In Australia, the population is highly urbanised, with over two-thirds of the national population living in the seven state capital cities (Australian Bureau of Statistics 2017). A perceived lack of democratic voice for rural and regional residents in public (and particularly environmental) policy making is often raised as an issue (Mercer-Mapstone et al. 2018). Perhaps because of this sensitivity, there is arguably more attention given to local voice in Australia than in the UK. This attention is evident by the number of public inquiries and reviews into unconventional gas development commissioned by 
various governments and agencies across Australia (currently at 14). Most of these reviews have the explicit intent to give local people a voice, with inquiries accepting public input, such as via hearings and submissions. Most of these inquiries have been conducted following the development of unconventional gas in Queensland, where formal avenues for local voice could be seen to be limited, e.g. through public consultation by consultancy firms during formulation of environmental and social impacts assessment that companies filed with the State's Coordinator-General prior to project approval. Other states have taken a very different approach to Queensland and, largely based on public opposition, have placed moratoria or bans on the practice of hydraulic fracturing.

In Queensland, the industry has been increasingly regulated by through legislative and policy changes, but initially, through the approvals process. Project proponents are required to submit detailed environmental impact assessment, which must include a social impacts assessment and a social impact management plan (SIMP). Within the SIMP, conditions are placed on the operations of the project to address concerns about distributive justice, in relation to workforce planning and accommodation (with recent prohibition of $100 \%$ external workforces for all resource development), conditions on the location and longevity of temporary workers camps, local content quotas for local procurement of goods and services, and the requirement to build local skills and quotas for Indigenous and female employees. A proportion of royalties paid to the state government on the sale of resources are distributed to all communities in the state, channelled through a competitive grants process.

Commonalities and differences in the two jurisdictions are recounted in Table 1. One should note that, in Australia (Queensland), coal seam gas was initially developed in rural areas (exploration activities closer to urban settlements were strongly opposed), where fewer people are directly affected.

Table 1. Contextual commonalities and differences that influence experiences of unconventional gas development

\begin{tabular}{|l|l|l|}
\hline Context & UK (England) & Australia (Queensland) \\
\hline $\begin{array}{l}\text { Population density } \\
\text { Location of gas projects }\end{array}$ & $\begin{array}{l}271 \text { people per square } \mathrm{km} \\
\text { in rural and semi-rural areas }\end{array}$ & $\begin{array}{l}\text { 3 people per } \mathrm{km}^{2}\left(2.8 / \mathrm{km}^{2}\right) \\
\text { Wells mainly in rural areas } \\
\text { (some in NSW, where exclusion } \\
\text { zones were introduced with a } \\
\text { 2km buffer zone around them- } \\
\text { adopted as voluntary best } \\
\text { practice by some companies in } \\
\text { Queensland) }\end{array}$ \\
\hline Petroleum licensing & $\begin{array}{l}\text { 'North American' model - low } \\
\text { government control over scale } \\
\text { and pace of development }\end{array}$ & $\begin{array}{l}\text { government intervention; free } \\
\text { market determines scale and } \\
\text { pace of development }\end{array}$ \\
\hline Private property rights & $\begin{array}{l}\text { Rights to 'exclusive use' } \\
\text { challenged and continue to be } \\
\text { challenged; e.g., trespass laws } \\
\text { changed to allow access at } \\
\text { 300m depth without surface } \\
\text { owner's consent }\end{array}$ & $\begin{array}{l}\text { Rights to 'exclusive use' } \\
\text { challenged but clarified with the } \\
\text { development of a land access } \\
\text { code of practice with dispute } \\
\text { resolution mechanisms. }\end{array}$ \\
\hline
\end{tabular}




\begin{tabular}{|l|l|l|}
\hline $\begin{array}{l}\text { Role of local government in } \\
\text { project approvals and } \\
\text { planning }\end{array}$ & $\begin{array}{l}\text { Increasing powers and } \\
\text { autonomy to local government } \\
\text { (but capacity issues) }\end{array}$ & $\begin{array}{l}\text { Central planning 'working with' } \\
\text { local governments }\end{array}$ \\
\hline Regulation & $\begin{array}{l}\text { Local powers can be usurped } \\
\text { Unpopular laws supporting the } \\
\text { industry instated }\end{array}$ & $\begin{array}{l}\text { Conditions on projects to seek } \\
\text { and respond to community } \\
\text { interests. }\end{array}$ \\
\hline
\end{tabular}

Table 1's summary of key contextual similarities and differences suggests that some similarities can be seen to be rooted in a shared history. There are also differences attributable to geography (e.g., Australia's lower population density) and governmental responses that reflect the relative intensity of onshore resource development in recent history, i.e., more mining development in Australia. We now explore how these differences influence experiences of community acceptance of unconventional gas development in the two countries.

\subsection{Community acceptance of unconventional gas development}

In the UK, the development of shale gas resources has been slow and relatively small in scale. The 'shale gas revolution' can at present be seen to be firmly located in North America, whilst the UK is being seen as a litmus test for Europe (Bradshaw and Waite 2017). Despite significant national and local media coverage, predominantly associated with the process of permissions ('the planning process'), protests have been modest and often localised to shale gas exploration sites.

As others have pointed out, the UK public appears to be largely ambivalent in its views toward shale gas development, but it perceives more risks than benefits (Whitmarsh et al. 2015). This conclusion is, according to surveys predominantly of those who live outside the zones of development. This result echoes the strongly negative voice that we have observed in the media and activist movements in Australia's urban areas, far from where gas development occurs.

Other public perception studies (Williams et al. 2017) highlight concerns regarding trustworthiness of institutional and government actors involved in the shale gas industry and the lack of transparent and democratic decision making - significant for our discussion later on social sustainability. These authors and others identify a dominant discourse where policy approaches are defined through a deficit model of public understanding of science (Evensen 2015). Within this frame of reference, a technical approach to feasibility and safety is seen as sufficient grounds for good policymaking (Williams et al. 2017). This positive technological assessment echoes the conclusions of the numerous public inquiries into the onshore gas industry in Australia, that any technical risks can be mitigated to acceptable levels (e.g., NSW Chief Scientist \& Engineer 2014; Scientific Inquiry into Hydraulic Fracturing in the Northern Territory 2018). Despite these findings, the public acceptability of unconventional gas development remains the subject of much debate in Australia (Luke et al. 2014; Espig and de Rijke 2016). Whilst UK citizens have described as largely ambivalent toward the industry, recent surveys suggest the ambivalence may be waning, as awareness of the industry grows (Department for Business, Energy and Industrial Strategy (DBEIS) 2018).

Likewise in Australia, there is growing 'anti-fracking' sentiment, particularly in the urban centres removed from that development. The shift in attitudes can be seen in media coverage of CSG development in Queensland. Initially, media focussed on regional economic benefits (Mitchell and Angus 2016), including jobs and growth. However, from 2010-11, the media coverage changed its 
tone, corresponding with release of the US anti-fracking film - Gasland, the emergence of the Australian protest movement - 'Lock the Gate', and Queensland government approval of four CSGto-liquid natural gas (LNG) megaprojects (Makki 2015).

During the CSG construction period, a 2014 survey of attitudes toward CSG development in affected communities found that most people either "tolerated" or "accepted" CSG, about a quarter "embraced" it, and fewer than 10 percent "rejected" the industry outright. However, when repeated in 2016 (after the construction period had ended), there was general tendency to more negative views although the majority still either "tolerated" or "accepted" the development (CSIRO 2016).

Public opinion about CSG development in Queensland is split, both in the agricultural regions of Queensland where the CSG is being developed and in the capital city of Brisbane, 200 kilometres away (Gillespie et al. 2016). The authors found that distrust of CSG companies was highest among rural landholders, exceeding 80 per cent, while residents in communities close to CSG development were evenly split between feelings of trust and distrust. There are also significant levels of distrust (one-third of those surveyed) in the government's ability to regulate the industry adequately (Gillespie et al. 2016), a finding that mirrors findings from the UK surveys.

There is also a 50-50 split in views among landholders with CSG infrastructure on their property of the industry's ability to operate generally within their contractual guidelines (Cavaye et al. 2017). More specifically, half of farmers claim that they are breaking even financially or gaining additional income from CSG development on their property. Half say that they are losing money due to land out of production and time spent fixing problems created by CSG crews, such as replacing fences or closing gates (Cavaye et al. 2017).

Community acceptance of unconventional gas in Queensland, Australia and England, UK can be seen to be shaped by similar expectations for democratic processes, involving fair and transparent decision making with acceptable avenues for public participation. Also in common are low levels of trust in government and industry to consider adequately a range of community and environmental values. Drawing from Evensen (2015), we focus on these aspects as elements of 'procedural fairness'. We recognise that a general definition of procedural fairness would include other elements as well.

There are also low expectations for benefit sharing across geographic scales. That is, there may be national benefits, but there are questions about whether they will be shared appropriately with the localities where development occurs. These questions we compare and discuss as elements of 'distributive justice' (Evensen 2015), again recognising that distributive justice includes others elements as well.

Both England and Australia have been heavily influenced by US experiences of shale gas, which assessment of the media suggests continues to dominate the thinking and discourse. Experiences of unconventional gas development in Australia appear to be more influenced by the US experience than the UK has been to date. The UK seems to be torn between a European philosophy of oil and gas development (the 'North Sea' model) that favours centralised control and moderated development with strong protection for cultural and environmental heritage values in landscapes, and more recent US influences that encourage development according to market forces with greater local government autonomy. 
Attitudes to unconventional gas development in Queensland, Australia and England, UK reflect experiences that provide a rich source of data for exploring further two key dimensions of community acceptance, or social license to operate (Moffat and Zhang 2015). In this comparison, we will focus on (1) experiences and discourses relating to land rights and land access as elements of procedural fairness and (2) discourses and experiences relating to the distribution of benefits and costs and its implications for social sustainability, in terms of economic wellbeing and retaining social capital.

\section{Procedural fairness in relation to land access}

There has been increasing research interest in the complex ethical dimensions of unconventional gas development with much academic work done already (see for example Lacey and Lamont 2014; Cotton 2016; Evensen 2017). For local citizens, procedural fairness is about having opportunities to participate in decision making, having their voice heard and concerns addressed, having enough relevant information to be able to participate fully, seeing transparency in industry operations and decision making, and addressing power imbalances between gas companies and landowners (Cotton 2014; Evensen 2015). Here, we examine these elements of procedural fairness in relation to land access processes and discourses of individual rights (such as exclusivity, privacy) and collective rights (such as energy security, landscape amenity, environmental protection) generated by unconventional gas development in each country.

\subsection{Debates about land access in the UK}

In the absence of widespread drilling for onshore gas in the UK, we reflect on processes for and discourse around property rights and land access from the different perspectives of broadly those who support shale gas development and those against. This reflection requires some initial conceptual definition.

The term land or property "access", when used with reference to natural resource extraction, is often under-theorized and poorly defined(Ribot and Peluso 2003).We use a simple definition of land access, borrowed from Ribot and Peluso (2003), which refers to the process of negotiating who gets the use of what and under which circumstances (Ribot and Peluso 2003). "Use" is defined as the enjoyment of some kind of benefit (Hunt 1998). In this specific context, the benefits in question are derived from underground access to gas reserves.

We previously discussed the legal and regulatory processes by which unconventional gas developers gain rights to drill on privately owned land. However, the law, whether based on or in an oral tradition, formal or customary, can never completely delineate all of the modes and pathways of resource access along complex and overlapping webs of power. In recognition of this complexity Schlager and Ostrom (2012) conceptualise property ownership as a "bundle of rights" that can be disaggregated and re-bundled as circumstances require. This "bundling" conceptualisation is relevant to natural resource management where access to different types of resources may be sought by different (individual and collective) actors. Schlager and Ostrom (2012) usefully distinguish between Authorised Users, Claimants, and Owners as having rights of access to resources. Of 
interest to us is the apparently increasing role of Claimants through what Ribot and Peluso (2013) have termed "socially acknowledged and supported claims or rights".

As the authors point out, NGOs and other movements of opposition through the concept of the 'Global Commons' have successfully shaped a climate change narrative that influences frameworks for resource access in the name of environmental protection. This shift is not without reason. The UK Government has made much of the collective benefits of shale gas production -citing employment opportunities, lucrative leasing deals and compensation payments to communities despite concerns that these benefits come at the expense of property rights of individuals (Short and Szolucha 2017). These authors cite the example of the UK Government proposal to allocate financial incentives for local councils and a 1 percent share of the production revenues to local communities (UK. DECC 2014) while simultaneously working to remove the right of property owners to be notified of planned fracking activities under their land. However, whilst the law is now clear regarding shale gas exploration and land access - the surface landowner must give permission; those who oppose shale gas exploration argue that the planning process associated with shale gas exploration is procedurally unfair.

For those who support shale gas development, the public good of allowing access to gas resources is the contribution to energy security in the UK energy mix that is a cleaner source of energy than coal (Whitton 2018). Beyond this narrative of wider collective benefits, for individual citizens and affected communities, the benefits are harder to identify. There are currently no compensation schemes in place for either landowner or the community as a whole. In the UK Government 2016 Budget, the Government announced the creation of a Shale Gas Wealth Fund as a mechanism to enhance distributional justice.

In sum, the land access debate in England, UK appears to focus on the processes of negotiating whether and how an onshore gas industry can and should enter the landscape. In contrast, the discourse in Queensland, where the industry already has a significant footprint, focuses on processes to disclose how the industry is operating and how it might enter new areas.

\subsection{Land access processes in Australia}

As in the UK, rights of private property holders to "exclusive use and enjoyment" of their land have been consistently challenged by the "bundle of rights" approach. This approach acknowledges the co-existent rights of non-owners (Schlager and Ostrom 1992) as the collective rights of mainly urbanbased 'claimants' are formally recognised in land use policy. For some landholders in Queensland, the granting of petroleum licences over their land, establishes gas companies as Authorised Users with rights of (negotiated) access and use. That has been a further erosion of private property rights (Turton 2015). In an attempt to balance landholders' rights to exclusive use with CSG development activities, the Queensland government developed specific procedures governing land access negotiations with a government body established ostensibly to protect the rights of landholders the Gas Fields Commission Queensland.

While private landholders have no right of veto against development, newly developed land access regulations require that a land access agreement, including a conduct and compensation agreement (CCA), must be negotiated with the landholder before entering private property. A land access agreement outlines the terms of access, including when and where access is permitted, how 
permitted activities must be conducted and the amount and method for compensation payments. The land access agreement is attached to the title of the land and is binding on subsequent landholders. For informed consent, the process for negotiating a CCA begins with the petroleum licensee providing a notice of intent to negotiate to the landholder, explaining the nature and scheduling of the proposed activities.

Negotiation of the CCA typically involves land-access agents and lawyers on behalf of the gas company and legal representation for the landowner. In recognition of the difference in financial resources between landowner and gas company, the company must pay for the landowner's lawyer, unless the two sides fail to reach agreement and sign a contract. If there is a failure to reach agreement, both parties can proceed to the recently appointed Ombudsman, free of charge, until an agreement is made. This provision though, places a financial constraint on a landholder's ability to resist the legal right of the gas company to access their land. In a general sense, one can see elements of procedural fairness, but the ability to gain certain outcomes is still limited by economic factors.

CCAs are negotiated on a case-by-case basis - there is no standard compensation amount. Embedded confidentiality clauses prevent landholders from divulging the terms of their agreements to others. In terms of both procedural fairness and distributive justice, the lack of transparency has resulted in significant differences in the amounts of compensation per well that landholders have received, with average agreements estimated at between $\$ 2,500$ per year (AgForce, personal communication) to $\$ 10,000$ per year (APPEA, personal communication). The secrecy surrounding the size of compensation payments has fostered suspicion and anxiety. That has been compounded by the rapid pace of CSG development that was observed, meaning that landholders reported feeling pressured to make decisions quickly. Cumulative psycho-social "stress" associated with negotiating land access agreements (as well as managing the effects of severe drought) are difficult to quantify, but they are cited by individuals in the community, government, and industry to be the most visible health impact of CSG development (Rifkin et al. 2017).

To address imbalances in capacity and information access among landholders, the leading agricultural industry group in the area 'AgForce,' has conducted a program of workshops to provide information and to build landholders' capacities to negotiate with CSG companies. The AgForce workshops are supported by interests across the spectrum - by their own membership funds as well as significant grants from the GasFields Commission Queensland and the oil and gas industry's peak body, the Australian Petroleum Production and Exploration Association (APPEA). To date, these workshops have reached hundreds of landholders out of more than 5,000 potentially affected landholders in the region. This multi-party support is worth noting as it relies on combined support from the oil and gas industry, the government regulator - who has been viewed with distrust by the invited participants, and a farm lobby group that had made early statements against CSG development.

In a general sense of procedural fairness, there are provisions in Queensland law and practice for "fair" negotiations. However, one also needs to consider the capacity to negotiate - the knowledge and the time as well as the financial resources, as noted above. These constraints can be doubly restricting during times of drought, as was felt in Queensland in the years leading up to the launch of CSG development. 
To regulate for procedural fairness, the Land Access Code was developed in Queensland in 2010. It has evolved over time to better clarify the roles and responsibilities of both landholders and gas companies and strengthen the rights of landholders by providing freely accessible dispute resolution mechanisms. There have also been provisions for "make good" agreements where resource activities have negatively impacted landholder use of water resources, in particular (Jacquet et al. 2018). Although predetermining what is to be negotiated and the requirement to negotiate, the code does not regulate the negotiation process itself. A recent study on the actual processes of land access negotiations found that concerns about procedural fairness remain a major issue for landholders (Curnow et al. 2017), particularly in relation to imbalances of power.

In Australia, unconventional gas companies must also negotiate with Aboriginal parties who formally or informally hold native title or cultural heritage rights and interests in the area proposed for development. Formally recognised native title rights holders can negotiate an Indigenous Land Use Agreement (ILUA) and are entitled to benefits arising from the development (Trigger et al. 2014). Providing procedural fairness for these groups remains a challenge for gas companies and governance bodies.

Table 2: Comparison of aspects of procedural fairness

\begin{tabular}{|c|c|c|}
\hline $\begin{array}{l}\text { Procedural fairness } \\
\text { elements } \\
\text { (Land Access) }\end{array}$ & England, UK & Queensland, Australia \\
\hline $\begin{array}{l}\text { Disclosure and } \\
\text { information }\end{array}$ & $\begin{array}{l}\text { Citizen access to information } \\
\text { incorporated in United Nations } \\
\text { Economic Commission for } \\
\text { Europe's } 1998 \text { Aarhus } \\
\text { Convention. In England, } \\
\text { supported by legislative changes } \\
\text { to public access of information } \\
\text { [e.g. Access to Information Act } \\
\text { 1985, the Freedom of } \\
\text { Information Act (FolA) } 2000 \text { and } \\
\text { Environmental Information } \\
\text { Regulations (EIR) 2004]. }\end{array}$ & $\begin{array}{l}\text { 'Informed consent'- Companies } \\
\text { must provide prior information } \\
\text { about when, where and what } \\
\text { activities will take place. } \\
\text { Confidentiality clauses on Land } \\
\text { Access agreements limit } \\
\text { information sharing among } \\
\text { landholders }\end{array}$ \\
\hline $\begin{array}{l}\text { Dispute resolution } \\
\text { mechanisms }\end{array}$ & $\begin{array}{l}\text { Agreement and compensation } \\
\text { mechanism for land access and } \\
\text { exploration up to } 300 \mathrm{~m} \text { below } \\
\text { ground. }\end{array}$ & $\begin{array}{l}\text { Once agreement (and } \\
\text { compensation) in place, difficult - } \\
\text { but not impossible - to adjust if } \\
\text { unforeseen impacts emerge } \\
\text { Recent appointment of a Gasfields } \\
\text { Ombudsman. The Ombudsman } \\
\text { has the power to investigate and } \\
\text { assess the administrative practices } \\
\text { and procedures of all government } \\
\text { departments, local governments } \\
\text { and public authorities }\end{array}$ \\
\hline $\begin{array}{l}\text { Participation and } \\
\text { communication }\end{array}$ & $\begin{array}{l}\text { Negotiated bilateral agreements } \\
\text { between landholders and } \\
\text { developer (unless access at } \\
300 \mathrm{~m} \text { or deeper) } \\
\text { Legal requirement for public } \\
\text { consultation during planning }\end{array}$ & $\begin{array}{l}\text { The mandatory Land Access Code } \\
\text { (2016) outlines best practice for } \\
\text { how parties should communicate, } \\
\text { consult and negotiate to maintain } \\
\text { effective working relationships, but }\end{array}$ \\
\hline
\end{tabular}




\begin{tabular}{|l|l|l|}
\hline & $\begin{array}{l}\text { application process in England. } \\
\text { Local Authority and developers } \\
\text { not required to respond to } \\
\text { consultees }\end{array}$ & $\begin{array}{l}\text { Inequalities remain in capacity to } \\
\text { negotiate and in information about } \\
\text { planned activities }\end{array}$ \\
& $\begin{array}{l}\text { Participation extends to public } \\
\text { meetings where plans are } \\
\text { discussed - public are not } \\
\text { involved in decision making }\end{array}$ & \\
\hline Impartiality & $\begin{array}{l}\text { Policy platform of "going all out } \\
\text { for shale" Cotton (2016) }\end{array}$ & $\begin{array}{l}\text { State government-based CSG } \\
\text { Compliance Unit as impartial } \\
\text { compliance monitoring of industry }\end{array}$ \\
\hline Third party rights & $\begin{array}{l}\text { Those opposed claim collective } \\
\text { rights to 'Global Commons' } \\
\text { (such as climate change and } \\
\text { environmental protection). } \\
\text { These rights influence land } \\
\text { access but have little to no } \\
\text { standing. }\end{array}$ & $\begin{array}{l}\text { Land access negotiations are } \\
\text { bilateral agreements between } \\
\text { company-landholder, or company- } \\
\text { Traditional Owner - no } \\
\text { opportunities for affected } \\
\text { community involvement. Third } \\
\text { party claims made through political } \\
\text { protest. }\end{array}$ \\
\hline
\end{tabular}

Both the UK and Australia have seen an increasing role of Claimants in discourse about property and access to resources. Their claims of collective rights to resources, such as Global Commons and landscape amenity are influencing the relationship between Owners and Authorised Users (i.e., landholders and gas companies). In Australia, there are perhaps more mature policies for addressing issues of "fairness" in land access, but these policies remain focussed on the bilateral relationship between gas companies and landholders. Further, the policies rely on technical and business aspects, such as the placement of wells and compensation, rather than on facilitating relationships of co-existence or moral considerations of justice, which are highlighted as necessary by Evensen (2015).

\section{The distribution of impacts on land, landscape and community}

Unconventional gas development has been shown to produce a range of impacts that can be experienced at local, regional and national scales (Jacquet and Kay 2014). As Been (1994) has pointed out, the benefits that natural resource exploration produce typically are diffused throughout society, while their costs and risks are concentrated on a relatively small group of neighbours. We will not repeat this general discussion on distributive justice relating to shale gas, as it has been offered elsewhere, (Evensen and Stedman 2016) and (Evensen 2017).Rather, we focus on a comparison of the experiences of unconventional gas development in England, UK and Queensland, Australia in terms of the distribution of impacts relating to land, landscape and, by default, associated communities and neighbours.

\subsection{Queensland impacts}

In Queensland, annual reporting of social and economic indicators shows that there were clear economic benefits for locally affected towns in terms of jobs creation, increased average wages, and total business income during the three-year construction phase (CCSG 2017). However, it appears that the distribution of opportunities can vary according to town size, capability and previous exposure to large scale projects (CCSG 2017). 
Table 3 outlines the type and nature of impacts experienced in Queensland to illustrate the imbalance between impacts and opportunities at sales of land versus landscapes.

\begin{tabular}{|c|c|c|}
\hline Impact & Land & Landscape/community \\
\hline $\begin{array}{l}\text { Economic- employment } \\
\text { opportunities }\end{array}$ & $\begin{array}{l}\text { Increased opportunities for 'off- } \\
\text { farm' work or second income for } \\
\text { landholders. } \\
\text { Some opportunities for } \\
\text { landholders to provide services, } \\
\text { e.g. well maintenance, cartage. }\end{array}$ & $\begin{array}{l}\text { Unemployment in affected } \\
\text { communities dropped to below } 2 \% \\
\text { during peak construction activities } \\
\text { (CCSG 2017). } \\
\text { Local skills shortages. Average } \\
\text { wage and salaries increased } \\
\text { (CCSG 2017) } \\
\text { Direct employment relied mostly on } \\
\text { non-resident workforce- either } \\
\text { drive in and out or fly in and out. } \\
\text { Mostly male, with efforts to } \\
\text { increase diversity (Indigenous and } \\
\text { female participation) }\end{array}$ \\
\hline $\begin{array}{l}\text { Economic-local } \\
\text { procurement }\end{array}$ & $\begin{array}{l}\text { Landholders may sell source } \\
\text { material such as sand and gravel, } \\
\text { or buy treated produced water to } \\
\text { increase farm productivity. }\end{array}$ & $\begin{array}{l}\text { Local procurement conditions but } \\
\text { some misconceptions about } \\
\text { definitions of "local" } \\
\text { Industry-funded local skills building } \\
\text { programs and apprenticeships }\end{array}$ \\
\hline Economic - housing & $\begin{array}{l}\text { Properties with wells values may } \\
\text { decrease (or increase if wells } \\
\text { provide an income stream) }\end{array}$ & $\begin{array}{l}\text { Rents doubled to tripled in some } \\
\text { towns; house sale prices doubled. } \\
\text { Lag time for new building } \\
\text { approvals and construction left an } \\
\text { oversupply of housing following the } \\
\text { construction activity and since, } \\
\text { both rents and house prices have } \\
\text { plummeted in the most affected } \\
\text { towns (CCSG 2017). }\end{array}$ \\
\hline Social-Traffic & $\begin{array}{l}\text { Increased traffic on otherwise } \\
\text { quiet rural properties disturbed } \\
\text { landholders, but also disturbed } \\
\text { privacy and caused concerns } \\
\text { about safety of children and } \\
\text { animals (Cavaye et al. 2017). }\end{array}$ & $\begin{array}{l}\text { Traffic infringements notices } \\
\text { increased significantly, partly due } \\
\text { to increased volumes of traffic but } \\
\text { also increased police presence } \\
\text { (CCSG 2017) } \\
\text { Heavy vehicle traffic through } \\
\text { towns- parents concerned about } \\
\text { children walking/cycling to school } \\
\text { (Rifkin et al. 2015) }\end{array}$ \\
\hline Social- Diversity & $\begin{array}{l}\text { Concerns about biosecurity with } \\
\text { traffic and overseas visitors }\end{array}$ & $\begin{array}{l}\text { Temporary migrant workers used } \\
\text { to fill some unskilled labour } \\
\text { shortages. Increased cultural } \\
\text { diversity. }\end{array}$ \\
\hline
\end{tabular}




\begin{tabular}{|l|l|l|}
\hline & & $\begin{array}{l}\text { "Outsiders" in town were mostly } \\
\text { welcomed but some feelings of lost } \\
\text { social identity in towns that } \\
\text { identified as "agricultural", now full } \\
\text { of "high-vis" work uniforms. }\end{array}$ \\
\hline Social- crime and safety & $\begin{array}{l}\text { Concerns for property security } \\
\text { with increased traffic and } \\
\text { "strangers" on the property }\end{array}$ & $\begin{array}{l}\text { Instances of opportunistic theft } \\
\text { rose in some local communities. } \\
\text { Theft was thought to be mostly } \\
\text { from unlocked work vehicles. }\end{array}$ \\
& $\begin{array}{l}\text { Fear of assault from predominantly } \\
\text { male "strangers" stopped women } \\
\text { from jogging at night. (There was } \\
\text { no corresponding evidence of } \\
\text { increase in sexual assault CCSG } \\
\text { 2017) }\end{array}$ \\
\hline Social -infrastructure & $\begin{array}{l}\text { New gates, driveway access, } \\
\text { tracks and fences as part of } \\
\text { compensation agreement. } \\
\text { Compensation may enable a } \\
\text { swimming pool or new fencing } \\
\text { and equipment to save } \\
\text { landholders time and effort. }\end{array}$ & $\begin{array}{l}\text { Regional and local road upgrades, } \\
\text { waste water treatment facility } \\
\text { upgrades, sporting facilities } \\
\text { upgrades, new housing, } \\
\text { community groups facilities and } \\
\text { grants for new equipment, events } \\
\text { sponsorship. }\end{array}$ \\
\hline
\end{tabular}

An assessment for the UK that is similar to that given above is not possible as the gas development there is not as advanced. That said, measures to address issues around the distribution of potential impacts have been addressed in England.

\subsection{Strategies to address issues of fairness in impact distribution}

We now examine strategies taken in England, UK and Queensland, Australia to address issues of fairness in the distribution of impacts and benefits. In the UK, the recently published Shale Wealth Fund (SWF) consultation document (Treasury 2016) from the UK Government states that local communities should have more control in local decisions, stating "the government believes in empowering local people, and wants to see communities and individuals have greater control of the decisions, assets, and services which affect them" (ibid: 5).

The Shale Wealth Fund document briefly presents a number of options for decision-making bodies for consultation and comment and includes provisions of economic compensation and benefits, for example:

1. Utilising an existing body in the local community (e.g., Parish or District Council), to administer funds.

2. Utilising an existing body to administer industry community benefits schemes

3. Establish an independent decision-making body to administer local level funding. 
The SWF is promoted as a fund that "could deliver up to $£ 1$ billion of funding" (ibid: 3 ), a portion of which could be directed toward local communities, thereby sharing "the benefits of shale developments" (ibid).

Whilst focusing on distribution of the financial benefits of shale gas development, the document specifically proposes elements of procedural fairness and democratic governance - such as participation, equity and representation. It suggests that local community representation should be reflected by those selected as decision-makers, and that local residents should be "as directly involved in decision-making as possible" (Treasury 2016, 13). However, as discussed earlier with reference to Short and Szolucha (2017), these benefits come at the expense of property rights of individuals. Also, this local decision making has proved not to be the case; instead, Government has simply ignored such promises (Whitton et al. 2017).

In Queensland, fairness in the distribution of impacts and benefits was primarily addressed through conditions placed on projects to force investment in local communities as part of the approval process. Conditions include mandatory requirements for local employment and local procurement as well as direct community investment.

Additionally, there were industry and government strategies to employ Aboriginal staff and to support Aboriginal enterprises. Some companies provided additional community investment, such as construction of housing for all of their staff who were permanently based in a community. The intent there was to decrease the stress on the local housing market. That stress could be seen in one town where weekly rents nearly tripled, a result consistent with the resource boom-bust cycles found in other regions (Jacquet and Kay 2014).

At the landscape scale, CSG companies contributed to boosting civic infrastructure. Their investments included construction of a new community centre, building a community swimming pool, constructing a trade-training centre at a local school, and co-funding construction of roads and a new sewage treatment facility (QGC 2016). These community investments were guided by a company's consultation with key stakeholders, such as in local government, as well as via regular meetings of community consultation committees, and by appointed members of a community investment panel. So, one can see here, as in the UK, elements of procedural fairness being observed in relation to addressing concerns about distributional justice.

Annual reporting on the socio-economic changes in gasfields communities shows an average 3 to 5fold increase in total business income in CSG affected communities during the three-year period of construction of CSG pipeline infrastructure (CCSG 2017). However, residents believed that only a few businesses benefitted to a large extent. Some of those businesses were reported to have overinvested to accommodate the construction boom, with bankruptcy following. Others, benefitting from local content expenditures or CCAs, have expanded agricultural holdings or invested in property in other parts of the state, such as the Brisbane metro region or in a vacation property on the coast.

This local investment is additional to royalty schemes and taxes that accrue to state government, such as the UK SWF. Some would see the range of spending in the region by the CSG companies, which has been reported annually, as generous and as due recognition that those who bear the burdens of CSG developments must be, and are being, compensated with benefits. However, 
whether this local spend reaches a balance considered as "distributive justice" hinges on matters of scale and actual distribution. Which sectors, and which actors, in the community benefit and how long does the benefit last? One can also question the extent to which that benefit is passed on within the community, or whether it is invested outside of the region. In Australia, attempts have been made to redress the imbalances, and reporting indeed showed economic benefits (CCSG 2017). However, there is evidence to suggest that these near-term results may only be temporary. Opportunities to harness the short period of intense investment (during the CSG construction period) appear to have been missed by a lack of coordinated vision and forward planning at company, local, and state government scales. One can thus see strategies toward achieving distributional justice in both jurisdictions. However, the Queensland experience, in particular, illustrates a measure of neglect of certain dynamics and some inherent economic and political mechanisms by which a "balanced" distribution can be frustrated.

\section{Conclusion}

A review of experiences of unconventional gas development in England, UK and Queensland, Australia in terms of procedural fairness and distributive justice reveal similarities and differences. The two countries have similar expectations about good governance and balancing the rights of private landholders with development that can be seen to be in the broader national interest. We noted how issues around distributive justice appear to invoke engagement processes that respect concerns for procedural fairness. That is, a range of interests are involved to varying degrees in both determining whether gas development proceeds and in allocating proceeds of development within communities where it does go forward. We have also identified elements of procedural fairness designed into mechanisms that are aimed to achieve distributional justice.

\subsection{Key differences between England, UK and Queensland, Australia}

In addition to the similarities noted, we have identified subtle but important differences, particularly around:

1. Who controls land use planning and decision-making differs. In the UK, powers have been given to local governments to approve unconventional gas development. These powers seem to be subject to being revoked if local planning decisions are not seen to be in the national interest). In Queensland, where onshore gas development is proceeding, priority development areas are designated by the state, with little influence at the local level on whether production proceeds.

2. The level of central government control over the scale and pace of exploration and development in licensing models is another area of difference. In the UK, development can be slowed or sped up as required. In Queensland, market forces determine the scale and pace of development. That has had implications for procedural fairness - with the level of CSG activity appearing to be beyond any formal local influence. This lack of control can be seen to have created additional 'stress' for landholders and affected communities.

3. The balance between individual and collective rights in relation to protecting aspects of the local and global environment differs. In the UK, discourse about shale gas development is framed as either economic prosperity or global climate change. In Australia, discourse about CSG development is less about any needed energy transition and more about local impacts, mainly 
land access rights, perceived environmental impacts (e.g. risks to aquifers that farmers rely on), local social impacts, and potential health impacts. These impacts are seen as the local burdens of an export commodity, that others, far away benefit from.

4. Mechanisms for working toward distributive justice differ. These mechanisms are only in the conceptual stages in the UK. In Australia, there is evidence of net economic gain from CSG development in Queensland. That has resulted from employment of residents, annual payments specified by conduct and compensation agreements, local procurement, direct social investment, and the distribution of infrastructure grants received by local governments, which are funded by state government-collected resource royalties. However, whether such mechanisms have achieved "justice" in their distribution within communities and between affected communities and residents elsewhere in the state remains a matter for further investigation.

\subsection{Context dependence}

The unconventional gas development experience appears to be context dependant as England, UK and Queensland, Australia differ in their stages of gas development and in the maturity of regulatory responses. Commonalities in th legal systems seem to present common concern about the elements of procedural fairness and distributive justice examined $i$ this paper. However, the manifestations of these principles in local experiences in each country are not described by a simple narrative, nor by snap-shot baseline and impact studies. Experience to date echoes the conclusions of the many public inquiries, essentially, that unconventional gas development requires rigorous monitoring of social, economic and environmental performance. Data from Queensland suggest that such development must be tailored to suit local requirements, such as for workforce solutions for the near-term construction boom and longer term for economic sustainability in a region that has been losing its young adults via outward migration. In relation to addressing such challenges, Queensland, Australia, can be seen to be more advanced than England, UK in relation to their gas development. One can see the regulatory mechanisms that are in place as an experiment in the English common law system, an experiment that is yielding insight. This evidence suggests a need to refine the mechanisms tried to attempt to enhance procedural fairness and distributive justice.

\subsection{Remedies?}

Whitton et al. (2015) proposed a conceptual framework for Social Sustainability as a mechanism by which to manage local conflict when considering land use and communities. Through this model, communities derive social priorities through "community visioning". Residents convene to identify and debate community values, highlight current issues and future opportunities, and co-develop plans to achieve an agreed vision. This approach promotes democracy in shale gas decisions and public participation in energy decisions through dialogue between government, industry and local communities, which can enhance procedural fairness in shale gas decisions and advances an overall concept of fairness.

However, such approaches face both practical and political challenges. For example, there is a tendency in practice to replace genuine engagement with "ticking the box" processes that lack development of a "learning dialogue" (Mercer-Mapstone, et al. 2017). Additionally, such processes can be seen to be aspirational, to be implemented in order to plan ahead rather than to redress 
immediate problems. Human history suggests that strategies calling for extensive foresight or beginning with a blank slate can be less useful in practice than more heuristic approaches that deal with the mess that has been made already (Jacquet et al., 2018).

We conclude that, in both settings, England, UK and Queensland, Australia the gas industry is still learning to be a "good neighbour". An emphasis on the term "learning" can be seen as important as it does not imply an ideal state, but a process wherein lessons are gained that can be employed to improve the regulation of the industry.

\section{References}

Australian Bureau of Statistics (ABS). 2017. Regional Population Growth, Australia 2016. http://www.abs.gov.au/ausstats/abs@.nsf/mf/3218.0 accessed 30 March 2018

Been, V. 1994. "Locally undesirable land uses in minority neighborhoods: Disproportionate siting or market dynamics?" Yale Law Journal 103, no. 6: 1383-422.

Bradshaw, M., and Waite C. 2017. "Learning from Lancashire: Exploring the contours of the shale gas conflict in England". Global Environmental Change 47, no. C: 28-36.

Cavaye, J., Kelly, L., Martin, M., Cameron, D., Rillorta-Goloran, T., Muriuki, G., and Baldwin, S. 2017. "Two industries on one landscape", presentation at the UQ/Agforce Research Forum, 17 November, Chinchilla. The University of Queensland.

Centre for Coal Seam Gas (CCSG). 2017. 2017 Annual Report: Queensland Gasfields Annual Socioeconomic Report. The University of Queensland Centre for Coal Seam Gas. https://boomtown-indicators.org/2016-annual-report

Cotton M.D. 2016. "Fair fracking? Ethics and environmental justice in United Kingdom shale gas policy and planning." Local Environment 22, no. 2: 185-202.

Cotton M.D. 2014. "Environmental Justice Challenges in United Kingdom Infrastructure Planning: Lessons from a Welsh Incinerator Project." Environmental Justice 7, no. 2 (2014): 39-44

CSIRO. 2016. Community attitudes towards CSG development: 2014 and 2016. Queensland. https://gisera.csiro.au/wpcontent/uploads/2015/11/AttitudesToCSG_2ppFactsheet_WEB_170215.pdf

Cuppen, E. 2018. "The value of social conflicts. Critiquing invited participation in energy projects." Energy Research \& Social Science 38: 28-32.

Curnow, K., Hunter, T., Weir, M., and Boulle, L. 2017. "Negotiation and regulation of land access agreements: lessons from Queensland." The Journal of World Energy Law \& Business 10, no. 2: 117-35.

DECC. 2014. Underground Drilling Access. London, UK: Department of Energy and Climate Change [online].

DECC. 2015 'Government defines Protected Areas for shale developments'. Department of Energy and Climate Change [online].

De Melo-Martín, I., Hays, J., and Finkel, M.L. 2014. "The role of ethics in shale gas policies." Science of the Total Environment 470-471, no. C: 1114-119.

Department for Business, Energy \& Industrial Strategy (DBEIS) 2018. Energy and Climate Change Public Attitudes Tracker (PAT): Wave 25 - summary report. https://assets.publishing.service.gov.uk/government/uploads/system/uploads/attachment data/file/702640/Wave_25_Summary_Report.pdf

Espig, M., and de Rijke, K. 2016. Unconventional gas developments and the politics of risk and knowledge in Australia. Energy research \& social science 20: 82-90.

Evensen, D. 2015. "Policy Decisions on Shale Gas Development ('fracking'): The Insufficiency of Science and Necessity of Moral Thought." Environmental Values 24, no. 4:511-34. 
Evensen D. 2017. On the complexity of ethical claims related to shale gas policy. Local Environment: 1-8.

Evensen D. and Stedman R. 2016. Scale matters: Variation in perceptions of shale gas development across national, state, and local levels. Energy Research and Social Science 20: 14-21.

Gillespie, N., Bond, C. J., Downs, V., and Staggs, J. 2016. Stakeholder trust in the Queensland CSG industry. The APPEA Journal, 56(1), 239-246.

Government H. 2015. The Onshore Hydraulic Fracturing (Protected Areas) Regulations 2015 (Draft Statutory Instruments - Petroleum). London, UK: The Stationary Office Ltd, 1-4.

House of Commons. 2016. "Comparison of the planning systems in the four UK countries." Commons Library Briefing Paper 0745920 January 2016.

https://researchbriefings.parliament.uk/ResearchBriefing/Summary/CBP-7459\#fullreport

Hunt R.C. 1998. "Concepts of Property: Introduction of Tradition. In: Hunt RC and Gilman A (eds)". Property in Economic Context. University Press of America, 3-28.

Hunter, T. 2014." Law and policy frameworks for local content in the development of petroleum resources: Norwegian and Australian perspectives on cross-sectoral linkages and economic diversification." Mineral Economics 27(2):115-126.

Innes, J., and Booher, D. 2004. "Reframing public participation: strategies for the 21st century." Planning Theory \& Practice 5(4):419-436.

Jacquet, J., and Kay, D. L. 2014. "The Unconventional Boomtown: Updating the impact model to fit new spatial and temporal scales." Journal of Rural and Community Development, 9(1).

Keywood, M., Grant, S., Walton, A., Aylward, L., Rifkin, W., Witt, K., Kumar, A., and Williams, M. 2018. "Human Health Effects of Coal Seam Gas Activity - A Study Design Framework." Final report to the Gas Industry Social and Environmental Research Alliance (GISERA). January 2018. CSIRO, Canberra. https://gisera.csiro.au/wp-content/uploads/2018/06/Health-1-FinalReport.pdf

Lacey, J., and Lamont, J. 2014. "Using social contract to inform social licence to operate: an application in the Australian coal seam gas industry." Journal of Cleaner Production, 84:831839.

Land Access Code 2016 (Queensland). Version 02. Department of Land Resources and Mines. http://www.slp.wa.gov.au.

Luke, H., Lloyd, D., Boyd, W., and Exter, K. 2014. "Unconventional gas development: Why a regional community said no." Geographical Research, 52(3): 263-279.

Makki, M. 2015. Coal Seam Gas Development and Community Conflict: A Comparative Study of Community Responses to Coal Seam Gas Development in Chinchilla and Tara, Queensland. The University of Queensland.

Mercer-Mapstone, L., Rifkin, W., Louis, W. R., and Moffat, K. 2018. "Company-Community Dialogue Builds Relationships, Fairness, and Trust Leading to Social Acceptance of Australian Mining Developments." Journal of Cleaner Production 184: 671-77.

Mitchell, L., and Angus, D. 2016. "From good news for business to good news for the news business." Unconventional Oil and Gas 3:35-39.

Moffat, K., and Zhang, A. 2014. "The paths to social licence to operate: An integrative model explaining community acceptance of mining." Resources Policy 39(1): 61-70.

New South Wales Chief Scientist \& Engineer. (2014). Final Report of the Independent Review of Coal Seam Gas Activities in NSW, Sydney: NSW Government.

North, D., Stern, P., Webler, T., and Field, P. 2014. "Public and stakeholder participation for managing and reducing the risks of shale gas development." Environ. Sci. Tech 48:83888396.

The Scientific Inquiry into Hydraulic Fracturing in the Northern Territory. 2018.The Scientific Inquiry into Hydraulic Fracturing in the Northern Territory, Darwin: Government of the Northern Territory. https://frackinginquiry.nt.gov.au/inquiry-reports/final-report 
Owen, J.R., and Kemp, D. 2013. "Social Licence and Mining: A Critical Perspective." Resources Policy 38(1): 29-35.

QGC .2016. QGC Submission: Senate Select Committee on Unconventional Gas Mining. Brisbane: QGC - https://www.aph.gov.au/DocumentStore.ashx?id=67eb1302-c5e4-4c6f-b109705 cc3cb0a4d

Queensland Government, Department of State Development, Manufacturing, Infrastructure and Planning, (2017). 'Strategic land use planning'. Canberra. https://www.statedevelopment.qld.gov.au/edq/strategic-land-use-planning.html

Rattle I, van Alstine, J., and Baker, T. 2018. "Shale gas development in England: a tale of two mineral planning authorities." In: Whitton J, Cotton, M., Brasier, K, and Charnley-Parry, I.M. (ed) Governing Shale Gas: Development, Citizen Participation and Decision Making in the US, Canada, Australia and Europe. Routledge.

Ribot , J.C., and Peluso, N.L. 2003. "A Theory of Access." Rural Sociology 68: 153-181.

Rifkin, W., Witt, K., Everingham, J. A., and Uhlmann, V. 2015. "Lessons CSG operators can learn from Southern Queensland towns." Gas Today 31:76-79.

Schlager, E. and Ostrom, E. 1992. "Property Rights Regimes and Natural Resources: A Conceptual Analysis." Land Economics 68:249-262.

Short, D., and Szolucha, A. 2017. "Fracking Lancashire: The planning process, social harm and collective trauma." Geoforum.

Stokes, R. 2012. "Defining the ideology of public participation: 'democracy, deliberation, devolution and dispute resolution' and a new system for identifying public participation in planning law," Macquarie Journal of International and Comparative Environmental Law 8(2): 1-20.

Szolucha, A. 2018. "Assessing risk from fracking in the UK and Poland: The limits of robust regulation and responsible development." In: Whitton J, Cotton, M., Brasier, K, and Charnley-Parry, I.M. (ed) Governing Shale Gas: Development, Citizen Participation and Decision Making in the US, Canada, Australia and Europe. Routledge.

Towler, B., Firouzi, M., Underschultz, J., Rifkin, W., Garnett, A., Schultz, H., Esternle, J., Tyson, S., and Witt, K. 2016. "An overview of the coal seam gas developments in Queensland." Journal of Natural Gas Science and Engineering 31:249-271.

Treasury, H. 2016. Shale Wealth Fund: Consultation. In: Treasury HM (ed). London: Crown Copyright.

Trigger, D., Keenan, J., de Rijke, K., and Rifkin, W. 2014. "Aboriginal engagement and agreementmaking with a rapidly developing resource industry: coal seam gas development in Australia." TheExtractive Industries and Society 1(2):176-188.

Turton, D. 2015. "Lawyers in Australia's coal seam gas debate: A study of participation in recorded community forums." The Extractive Industries and Society 2: 802-812.

UK. Department of Energy and Climate Change (DECC). 2015. "Government defines Protected Areas for shale developments". https://www.gov.uk/government/news/government-definesprotected-areas-for-shale-developments.

Whitmarsh, L., Nash, N., Upham, P., Lloyd, A., Verdon, J.P., and Kendall, J.M. 2015. "UK public perceptions of shale gas hydraulic fracturing: The role of audience, message and contextual factors on risk perceptions and policy support." Applied Energy 160: 419-430.

Whitton, J., Brasier, K., Charnley-Parry, I.M, Brasier, K., and Cotton, M.D. 2017. "Shale gas governance in the United Kingdom and the United States: Opportunities for public participation and the implications for social justice." Energy Research \& Social Science 26: 11-22.

Whitton, J., Cotton, M.D., Brasier, K., and Charnley-Parry, I.M. 2018. "Introduction: Governing Shale Gas." In: Whitton J, Cotton, M., Brasier, K, and Charnley-Parry, I.M. (ed) Governing Shale Gas: Development, Citizen Participation and Decision Making in the US, Canada, Australia and Europe. Routledge. 
Whitton, J., Charnely-Parry, I.M., Akiyoshi, M., and Lawless, W. 2015. "Conceptualizing a social sustainability framework for energy infrastructure decisions." Energy Research \& Social Science 8: 127-138.

Williams, L., Macnaghten, P., Davies, R., and Curtis, S. 2017. "Framing 'fracking': Exploring public perceptions of hydraulic fracturing in the United Kingdom." Public Understanding of Science (Bristol, England) 26: 89-104. 